\title{
An Unusual Pediatric Case with Spontaneous Pneumoperitoneum: Pneumatosis Cystoides Intestinalis Induced by Constipation
}

\section{Spontan Pnömoperitoneumu Olan Olağan Dışı bir Pediatrik Vaka: Kabızlığın Neden Olduğu Pnömatozis Sistoides Intestinalis}

\section{Oktay Ulusoy $\oplus$, Efil Aydın®, Osman Zeki Karakuş®, Yasin Ertuğ Çekdemirø, Oğuz Ateş®}

Cite as: Ulusoy $\mathrm{O}$, Aydın E, Karakuş OZ, Çekdemir YE, Ateş $\mathrm{O}$. An unusual pediatric case with spontaneous pneumoperitoneum: pneumatosis cystoides intestinalis induced by constipation. Forbes J Med. 2021;2(1):58-61.

\begin{abstract}
Pneumoperitoneum almost always indicates a perforation. However, perforation is not detected approximately $5 \%$ to $15 \%$ of all exploratory laparotomies and it is called spontaneous pneumoperitoneum (SP). One of the rare causes of SP is Pneumatosis cystoides intestinalis (PCI). An 11-year-old female patient was transferred to the pediatric emergency department due to suspicion of intestinal perforation. Erect abdominal X-ray revealed pneumoperitoneum below the right diaphragm. Emergent exploratory laparotomy was performed. No perforation was detected during exploratory laparotomy. Both the absence of fever, peritoneal irritation signs and normal biochemical parameters SP must be considered. It should be kept in mind that PCI induced by constipation may be a cause of SP.
\end{abstract}

Keywords: Spontaneous pneumoperitoneum, perforation, pneumatosis cystoides intestinalis

öz

Pnömoperitoneum hemen her zaman perforasyonu gösteren bir durumdur. Bununla birlikte, tüm laparotomilerinin yaklaşık \%5 ile \%15'inde perforasyon tespit edilmez ve bu durum spontan pnömoperitoneum (SP) olarak adlandırılır. SP'nin nadir nedenlerinden biri Pnömatozis sistoides intestinalis (PCI) 'dir. 11 yaşında kız hasta perforasyon şüphesiyle çocuk acil servisine sevk edildi. Ayakta direk karın grafisinde sağ diyaframın altında serbest hava saptandı. İntestinal perforasyon şüphesi ile acil laparatomi yapılan hastada perforasyon saptanmadı. Ateş ve peritoneal tahriş belirtilerinin olmaması ve normal biyokimyasal parametreler SP düşündürmelidir. Kabızlığın neden olduğu PCI'in SP'nin nadir bir nedeni olabileceği unutulmamalıdır.

Anahtar kelimeler: Spontan pnömoperitoneum, Perforasyon, Pnömotozis sistoides intestinalis
Received/Geliş: 04.01.2021

Accepted/Kabul: 15.01.2021

Publication date: 27.04.2021

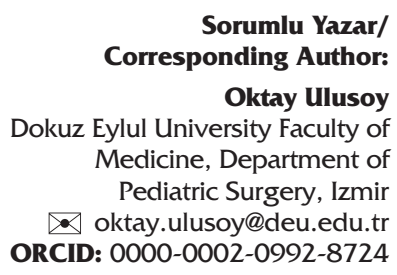

Sorumlu Yazar/ Corresponding Author:

Oktay Ulusoy

Dokuz Eylul University Faculty of Medicine, Department of Pediatric Surgery, Izmir oktay.ulusoy@deu.edu.tr ORCID: 0000-0002-0992-8724

E. Aydın 0000-0003-1467-6100

O.E. Karakuş 0000-0002-5083-3647

O. Ateş 0000-0001-7267-941X

Dokuz Eylul University Faculty of Medicine, Department of Pediatric Surgery, Izmir

Y.E. Cekdemir 0000-0002-3713-8826

Dokuz Eylul University Faculty of Medicine, Department of Radiology, Division of Pediatric Radiology, Izmir 


\section{INTRODUCTION}

Pneumoperitoneum almost always indicates an intestinal perforation and requires emergent surgical intervention in more than $90 \%$ of cases. ${ }^{1}$ However, perforation is not detected in approximately $5 \%$ to $15 \%$ of all exploratory laparotomies is called spontaneous pneumoperitoneum (SP). ${ }^{2}$ Intrathoracic, abdominal, gynecological, iatrogenic and miscellaneous etiologies may cause $\mathrm{SP}^{3,4}$ A rare cause of SP is pneumatosis cystoides intestinalis (PCI). ${ }^{5}$ Regardless of reasons, SP may cause a dilemma for the pediatric emergency specialists and pediatric surgeons.

In the literature, one adult case has been reported showing a relationship between $\mathrm{SP}$ and $\mathrm{PCl}$ induced by constipation. ${ }^{6}$ Herein, we report a pediatric case with SP. To the best of our knowledge, this is the first pediatric case presentation showing coexistence of $\mathrm{SP}$ and $\mathrm{PCl}$ induced by constipation.

\section{CASE}

An 11-year-old female patient was transferred to the pediatric emergency department (ED) from an external center due to suspicion of intestinal perforation. Complaints of patient were right upper quadrant pain, shoulder pain and nonbilious vomiting. Free air has been detected under the right diaphragm on erect abdominal X-ray. She had no history of acute or chronic respiratory disease, abdominal surgery, trauma or chronic medication use.

On physical examination, the patient was afebrile with normal vital signs. Chest breath sounds were equal bilaterally. The patient had no subcutaneous emphysema, abdominal distention and defense or rebound tenderness on abdominal examination. The painless solid mass was palpated in the pelvic area. Laboratory values showed normal leukocyte count $\left(9500 / \mathrm{mm}^{3}\right)$, hemoglobin value $(12.4 \mathrm{~g} / \mathrm{dl})$ and platelet count $\left(329000 / \mathrm{mm}^{3}\right)$. Coagulation parameters and other biochemical parameters were within normal limits. No pneumothorax or pneumomediastinum was detected on the chest radiography. Erect

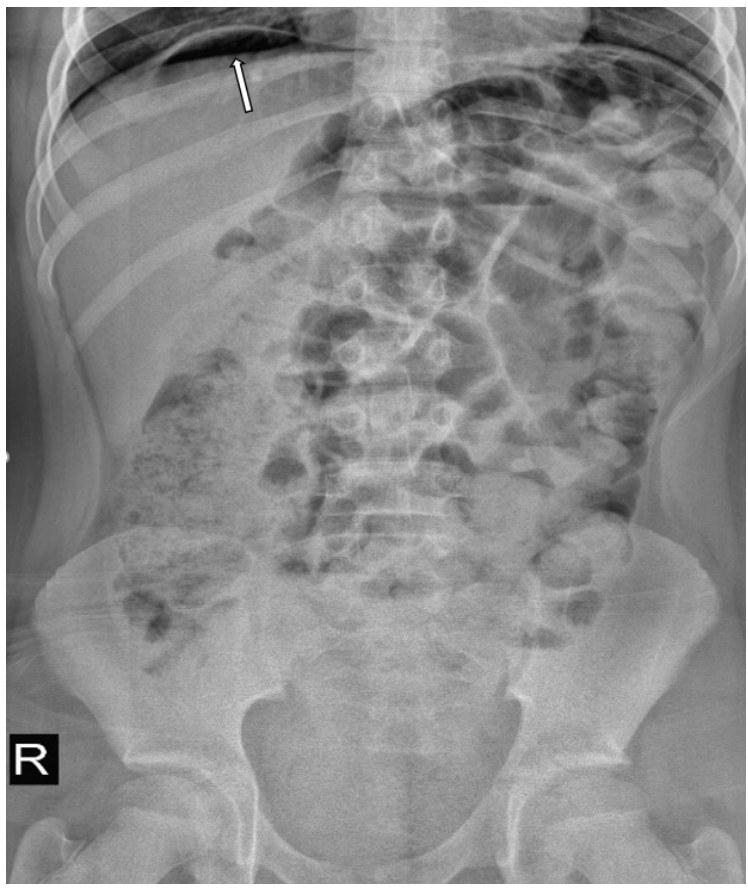

Figure 1. Free air below the right diaphragm on X-ray (arrow).

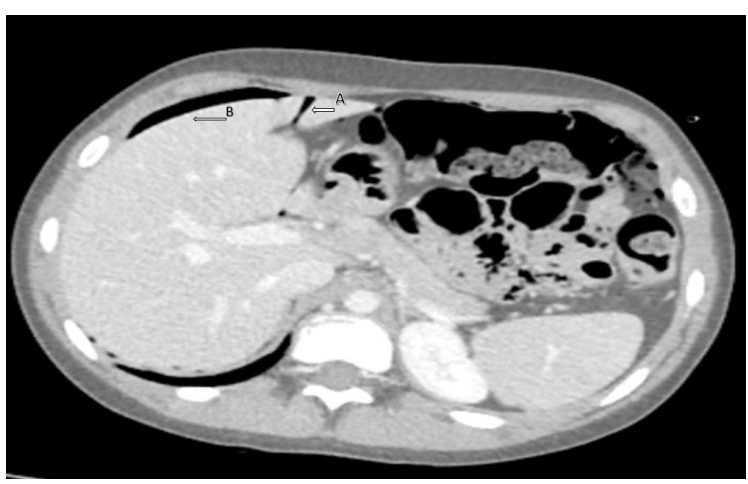

Figure 2. Free air in the Falciforme ligament (A) and intraperitoneal area (B).

abdominal X-ray has been reported as pneumoperitoneum below the right diaphragm (Figure 1). Abdominal CT has been performed due to detecting palpable mass in physical examination. Abdominal CT has been reported as free air in the abdominal cavity, retroperitoneum and falciform ligament (Figure 2). In addition, a large amount of feces was seen in the colon and rectum. Since perforation could not be ruled out, emergent exploratory laparotomy was performed.

\section{Operative Procedure}

Under general anesthesia with endotracheal intubation, the patient was placed in the supine 
position. A nasogastric tube was placed perioperatively. Upon entering the peritoneum, a small egress of gas was noted. There was no free fluid in the abdominal cavity. When the distal esophagus, stomach and duodenum were evaluated, there was no evidence of perforation. Both leaflets of the diaphragm were intact. The air was injected into the nasogastric tube to evaluate stomach and there was no evidence of air leakage. The ascending, transverse and descending colon were mobilized and examined, any evidence of perforation was not detected. The huge fecalomas were detected in the whole colon. Laparotomy was terminated and position of patient was converted from supine to lithotomy position. Total colonic irrigation was applied and fecalomas were evacuated. Preoperative abdominal CT was re-evaluated by pediatric radiology department. $\mathrm{PCl}$ was detected in the ascending, transverse and descending colon (Figure 3). Oral intake started on the postoperative $2^{\text {nd }}$ day and the patient was discharged on the postoperative $4^{\text {th }}$ day with maintenance of treatment for constipation.

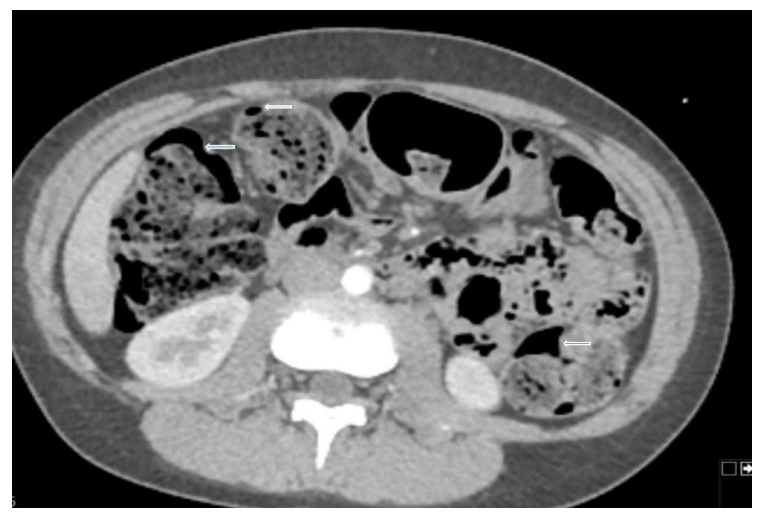

Figure 3. Abdominal CT revealed PCI in colon (arrow)

\section{DISCUSSION}

Visceral perforations usually present with signs of peritonitis. Biochemical acute phase reactants have been found almost always increased. ${ }^{1,3}$ Improper evaluation of visceral perforations may endanger the lives of pediatric patients. Extensive surgery is performed to detect SP, but perforation cannot be detected. This situation may create a surgical dilemma for surgeons in terms of treatment strategies. In the present case, the patient did not demonstrate signs of peritoneal irritation on physical examination and levels of acute phase reactants were within normal limits.

Although in a number of case reports, any etiologic factors have not been indicated, still SP with different etiologies has been classified in the literature. ${ }^{3,4}$ The SP may be commonly observed after the post-abdominal surgery, postcolonoscopy, peritoneal dialysis and blunt trauma. ${ }^{1-3,6}$ The SP may occur when air passes upward through genital tract via the uterus and fallopian tubes. Unlike to adult cases with SP, gynecologic etiologies of SP are rare in pediatric population. ${ }^{2}$ Thoracic etiologies including mechanical ventilation, pneumothorax, bronchoperitoneal fistula and pneumomediastinum are more common in pediatric patients. ${ }^{2}$ Emphysematous cholecystitis, spontaneous bacterial peritonitis, liver abscess and $\mathrm{PCI}$ are etiologic factors for the development of intraabdominal SP. ${ }^{1-3,5-7}$

As a characteristic feature of $\mathrm{PCl}$, intramural gas filled cysts in the gastrointestinal tract are seen. If these cysts rupture into the intraabdominal cavity SP may occur. ${ }^{2,5,8} \mathrm{PCl}$ is generally associated with other primary diseases. Necrotizing enterocolitis, peptic ulcers, pyloric obstruction, intestinal obstruction, inflammatory bowel disease and connective disease may cause SP in childhood. ${ }^{2,5,7}$ In the literature, there is one adult case report about SP related to $\mathrm{PCI}$ induced by constipation. ${ }^{6}$ In the present case, there is no history of hospitalization, trauma, chronic disease, medications or surgery. In this case, evidence of perforation was not detected during extensive laparotomy. The patient was successfully treated after negative exploratory laparotomy with total colonic irrigation and oral treatment for constipation. Our patient was discharged on the $4^{\text {th }}$ postoperative day without any problem.

The operative treatment may not always be necessary for pneumoperitoneum. The clinicians must analyze medical history, physical examination findings, laboratory and imaging results of the patients. In the absence of signs of peritoneal irritation, fever, increased levels of 
acute phase reactants, severe abdominal pain or abdominal distension, SP must be considered. Preoperative abdominal CT should be evaluated in detail with consideration of PCI. It should be kept in mind that $\mathrm{PCl}$ induced by constipation may be a cause of SP. Symptoms can regress, if the constipation is treated. Careful differentiation of SP from pneumoperitoneum induced by intestinal perforation may reduce unnecessary operative intervention in childhood.

\section{Conflict of Interest: None. \\ Funding: None. \\ Informed Consent: None.}

\section{REFERENCES}

1. Gutkin Z, Iellin A, Meged S, et al. Spontaneous pneumoperitoneum without peritonitis. Int Surg. 1992; 77: 219-22.

2. Karaman A, Demirbilek S, Akin M, et al. Does pneumoperitoneum always require laparotomy? Report of six cases and review of the literature. Pediatr Surg Int. 2005; 21(10): 819-24.

https://doi.org/10.1007/s00383-005-1489-3
3. Mularski RA, Sippel JM, Osborne ML. Pneumoperitoneum: a review of nonsurgical causes. Crit Care Med. 2000; 28(7): 2638-44. https://doi.org/10.1097/00003246-20000700000078

4. Gant Jr CB, Daniel WW, Hallenbeck GA. Nonsurgical pneumoperitoneum. Am J Surg. 1977; 134: 411-4. https://doi.org/10.1016/0002-9610(77)90418-4

5. Du Vernoi JG: Anatomische Beobachtungen der unter der äussern und innern Haut der Gedärme eingeschlossenen Luft. Phys Med Abhandl Akad Wiss Petersb. 1783; 2: 182-8.

6. Yamana I, Noritomi T, Takeno S, et al. Spontaneous pneumoperitoneum due to constipation. Case Rep Gastroenterol. 2015; 9(3): 361-5. https://doi.org/10.1159/000441999

7. Tallant C, Tallant A, Nirgoitis J, et al. Spontaneous pneumoperitoneum in pediatric patients: A case series. Int J Surg Case Rep. 2016; 22: 55-8. https://doi.org/10.1016/j.ijscr.2016.03.017

8. Ueda T, Tanaka T, Yokoyama T, et al. Spontaneous pneumoperitoneum with duodenal diverticulosis in an elderly patient: a case report. Surg Case Rep. 2020 Jan 6; 6(1): 3.

https://doi.org/10.1186/s40792-019-0769-4 